\title{
The Cultural School of Strategic Formulation (Strategy Formulation Based on Social Interactions, Beliefs and Traditions)
}

\author{
Christian Narh Opata1, Alfred Sarbah ${ }^{2}$, Angela Nusenu1, Stephen Tetteh ${ }^{3}$ \\ ${ }^{1}$ Schoolof Management and Economics, University of Electronic Science and Technology of China (UESTC), Chengdu, China \\ ${ }^{2}$ Management Studies Department, School of Business, Kumasi Technical University, Ghana \\ ${ }^{3}$ School of Management, Hefei University of Technology, Hefei, China \\ Email:chrisrui@yahoo.com,sarbah@yahoo.com,papawasty21@yahoo.com
}

How to cite this paper: Opata, C.N., Sarbah, A., Nusenu, A. and Tetteh, S. (2017) The Cultural School of Strategic Formulation (Strategy Formulation Based on Social Interactions, Beliefs and Traditions). Open Journal of Business and Management, 5, 335-347.

https://doi.org/10.4236/ojbm.2017.52029

Received: March 28, 2017

Accepted: April 27, 2017

Published: April 30, 2017

Copyright () 2017 by authors and Scientific Research Publishing Inc. This work is licensed under the Creative Commons Attribution International License (CC BY 4.0).

http://creativecommons.org/licenses/by/4.0/

\begin{abstract}
The cultural school of strategy formulation is one of the 10 schools of thought identified by Henry Mintzberg et al. in their book Strategy Safari. The cultural school, having its roots in anthropology, focuses on social interaction based on beliefs and traditions shared by members of an enterprise. The foundation of the Cultural School is built on the idea that if you "hold power up to a mirror the reverse image you see is culture". The main points of this model as outline in literature are: decision-making style, resistance to strategic change, overcoming the resistance to strategic change, dominant values, and culture clash. Although the model is limited in its conceptual vagueness and its ability to discourage necessary change, however, the culture school assumes a rich historical approach and introduces ideas of collectivism. Culture provides an effective and durable barrier to imitation and thereby enables organizations to enjoy competitive advantages. Toyota infused their company with culture and it is a foundational part of their business model (The Toyota Way).
\end{abstract}

\section{Keywords}

Competitive Advantage, Cultural School, Culture, Strategy Formulation, Strategy

\section{Introduction}

Since the beginning of the 1980s, Organization culture has been given much prominence in literature [1]. There have been lots of research on how organizational culture impacts on the success or otherwise of organizations. [2] Opined that culture, like leadership, is very important for the success of an organization 
and that one cannot function without the other. Irrespective of where we find ourselves, we see culture around us; as in the food we eat, music we dance to, the language we speak, and even how we associate with people. Culture is viewed as a resource that enables organizations to achieve competitive advantage because of its imitable capabilities. Corporate Culture is a set of values, beliefs and behavior patters that form the basic identity of an organization and have their origin in the thinking of the founders, evolving over time by the accumulation of experiences, new social trends and the changing values of managers up to the present day [3].

Organizational culture matters because cultural elements determine strategy [2]. According to A choice of a firm's strategy is highly influenced by its strengths and weaknesses referred to as its internal environment and also by the opportunities and threats that the external environment presents. Irrespective of a particular choice that a firm chooses in its strategic process, the main objective is to achieve competitive advantage. Strategic management involves three stages; formulation, implementing and evaluating. This paper, however, is mainly concerned with strategy formulation based on the Cultural School as championed by Henry Mingtzberg. According to [4], strategy formulation involves developing a vision and mission, identifying an organization's external opportunities and threats, determining internal strengths and weaknesses, establishing longterm objectives, generating alternative strategies, and choosing particular strategies to pursue.

This paper explores the Cultural School of strategy formulation and how it is applied at Toyota Motor Corporation. It discusses the premise of the school, the relationship between culture and strategy, culture as a key resource in achieving competitive advantage, contributions and weaknesses of the Cultural School. The paper also looks at a case analysis at Toyota Motor Corporation.

\section{Background of the Culture School}

\subsection{Strategy Formation as a Collective Process}

Culture is a common shared set of beliefs and meanings acquired through the infusion of values. According to the cultural school, with its roots in anthropology, strategy systems are described to be processes of social interaction, based on the beliefs and understandings shared by the members of an enterprise. Culture is hardly a new idea. Every field of study has its central concept-market in economics, politics in political science, strategy in strategic management, and so on-and culture has long been the central concept in anthropology. From the vantage point of anthropology, culture is all around us-in the food we drink, the music we listen to, the way we communicate. At the same time, culture is what is unique about the way we do all these things. It is about what differentiates one organization from another, one industry from another, one nation from another.

An individual acquires these beliefs through a process of acculturation, or socialization, which is largely tacit and nonverbal, although sometimes reinforced 
by a more informal indoctrination. The members of an enterprise can, therefore, only partially describe the beliefs that underpin their culture, while the origins and explanations may remain obscure. As a result, strategy takes the form of perspective above all, more than positions, rooted in the collective intentions (not necessarily explicated) and reflected in the patterns by which the deeply embedded resources, or capabilities, of the enterprise are protected and used for competitive advantage. Strategy is therefore best described as deliberate (even if not fully conscious). Culture and especially ideology do not encourage strategic change so much as the perpetuation of existing strategy. At best "they tend to promote shifts in position within the enterprise overall strategic perspective."

As opposite to the power school that focuses on self-interest and fragmentation, the cultural school focuses on common interest and integration.

$>$ Strategy formation is viewed as a social process rooted in culture.

$>$ The theory concentrates on the influence of culture in discouraging significant strategic change.

$>$ Culture became a big issue in the United States and Europe after the impact of Japanese management was fully realized in the 1980's and it became clear that strategic advantage can be the product of unique and difficult-to-imitate cultural factors.

Culture can be studied as an outsider looking on or from the perspective of the native inside. The first takes an objective stand on why people behave as they do, which is explained by the uniqueness of social and economic relationships. The second considers culture as a subjective process of interpretation, not based on any abstract, universal logic. The school concern itself largely with the influence of culture in maintaining strategic stability and sometimes in actively resisting strategic change.

\subsection{Premises of the Cultural School}

According to [5], the Cultural School is premise on five (5) main beliefs. These beliefs are summarized as below

1) Strategy formation is a process of social interaction, based on the beliefs and understandings shared by the members of an organization.

2) An individual acquires these beliefs through a process of acculturation, or socialization, which is largely tacit and nonverbal, although sometimes reinforced by more formal indoctrination.

3) The members of an organization can, therefore, only partially describe the beliefs that underpin their culture, while the origins and explanations may remain obscure.

4) As a result, strategy takes the form of perspective above all, more than positions, rooted in collective intentions (not necessarily explicated) and reflected in the patterns by which the deeply embedded resources, or capabilities, of the organization are protected and used for competitive advantage. Strategy is therefore best described as deliberate (even if not fully conscious).

5) Culture and especially ideology do not encourage strategic change so much 
as the perpetuation of existing strategy; At best, they tend to promote shifts in position within the organization's overall strategic perspective.

\subsection{Culture and Strategy}

Organizational Culture was only given attention in literature in the 1980s [1]. In England, Andrew Pettigrew (1985) as cited by [5] conducted a detailed study of the British chemical company, ICI that revealed important cultural factors, while in the United States, Feldman (1986) considered the relationship of culture to strategic change and Barney (1986) asked whether culture could be a source of sustained competitive advantage, all cited by [5].

Much like the stakeholder approach to designing power relationships, there is a literature on handy techniques to design culture, which in my opinion belongs in the planning school, as the following quotation should make clear: "To match your corporate culture and business strategy, something like the procedures outlined above [four steps] should become a part of the corporation's strategic planning process" (Schwartz and Davis, 1981: 41) cited by [5].

Organizational culture to a very large extent is critical because cultural elements determine strategy, goals, and modes of operating [2]. [2] posited that culture cannot be separated from strategy because in organizations, strategic thinking is deeply colored by tacit assumptions about who the organization is and what their mission is. [5] summarized the linkage between culture and strategy into five (5) main sub-headings as explained below.

1) DECISION-MAKING STYLE. Culture influences the style of thinking favored in an organization as well as its use of analysis, and thereby influences the strategy-formation process. [6] concluded that strategy formulators should select a strategy that is compatible with the prevailing culture of the organization.

2) RESISTANCE TO STRATEGIC CHANGE. A shared commitment to beliefs encourages consistency in an organization's behavior, and thereby discourages changes in strategy. However, culture in organizations naturally resists strategic change. When a way to do things, a style, or belief is shared by the organization's members, the organization develops a consistent behavior a culture that is difficult to be replace. Culture can be a constrain to an organizations strategy as a culture that has proved very much successful in the past will make it difficult for members to change in response to changes in the environment [2].

3) OVERCOMING THE RESISTANCE TO STRATEGIC CHANGE: In overcoming the challenge where by culture becomes a barrier to strategic change, Lorsch (1986) as cited by [5] suggested that top managers must accept as a major part of any company's culture the importance of flexibility and innovation. Changes in strategy have to be premised on changes in organizational culture. Montanari et al. (1990) as cited by [6] argues that strategy will only succeed when it aligned with the organizational culture. Bjorkman (1989) cited by [5] overcoming resistance to change occurs in just four phases and these are: Strategic drift, breaking-down of the current culture, trial and re-formulation and stabilization. 
4) DOMINANT VALUES: Values such as service, quality, and innovation, which provides competitive advantage dominates successful organizations. Companies therefore, can develop a strong culture based on those values.

5) CULTURE CLASH. There is a culture clash when two companies merge and this in most cases as reported in the merges and acquisitions in the 1980s resulted in derailing the union and the inability of these unions to fulfill expectations. While the combination of two firms may make sense from a "rational" product or market point of view, the less apparent cultural differences may serve to derail the union. Strategies for joint ventures or mergers will be problematic as these two companies are very much different and unique in their culture.

\subsection{Culture as a Key Resource in Achieving Competitive Advantage}

The Resource-base model assumes that each organization is a collection of unique resources and capabilities and as a such, the uniqueness of its resources and capabilities is the basis of a firm's strategy and its ability to earn above-average returns [7]. The model points out that advantages in the market place can only be sustained when it relies on resources that are rare, inimitable, and for which competitors cannot find substitutes. The model is meant to prevent imitation from competitors. Firms are able to achieve competitive advantage when their strategies are not been copied by other firms.

According to Barney (1986) as cited by [5], culture is the most effective and durable barrier to imitation. His two reasons are that; first, culture encourages the production of unique outcomes and secondly, culture itself is ambiguous making it difficult to understand let al. one imitate. The Europeans invented the automobile by their skilled workforce and artisans as a luxury for the rich. The Americans, however, limited in skilled labor and artisans, used unskilled workforce to produce a standardized and low-cost automobile. The Europeans later tried to imitate the Americans as the Americans have taken over the automobile industry but in as much as they tried, they fail. This is because they were all operating on different cultures. The Japanese also failed to copy the Americas' way of producing cars and later developed their own way of producing automobiles that is aligned with their culture.

\subsection{Critique and Contribution of the Cultural School}

One danger of this school is that it can discourage necessary change. It favors the management of consistency, of staying on track, so to speak. Culture is heavy, established, set; resources are installed, rooted. By emphasizing tradition and consensus as well as by characterizing change as so complex and difficult, this school can encourage a kind of stagnation. While culture itself may be difficult to build in the first place, and even more difficult to reconstruct later, it is rather easy to destroy. Another danger of culture as an explanatory framework is that it equates strategic advantage with organizational uniqueness. Being different is often good, but not in and of itself, for that can breed a certain arrogance. 
Paradoxically, theories such as the resource-base may exacerbate this tendency. They provide managers with a ready-made vocabulary by which to justify the status quo. Any organizational practice that seems incomprehensible can be justified on the grounds of inimitability: it may be ever so tacit, based on the resources that are themselves ever so rare. The ambiguities associated with resources may help to explain why successful strategies can go unchallenged for a long time, but they do not let managers know when and how to go about challenging them. Should the managers try to disentangle the successful strategies-reverse engineer them, so to speak-or should they simply try to create other strategies that are equally ambiguous to other firms?

And then there is the problem raised above about imbalance. It is not corrections we need in this field-a focus on internal resources after an obsession with external competition-but a sense of balance between all the appropriate factors. All of this applies especially to certain kinds of organizations-clearly those more "missionary" in nature, with rich cultures; also to large, established organizations whose stagnant cultures reinforce their long-standing strategies. The cultural school also seems most applicable to particular periods in the lives of organizations. This includes a period of reinforcement, in which a rich strategic perspective is pursued vigorously, perhaps eventually into stagnation. This generally leads to a period of resistance to change, in which necessary strategic adaptation is blocked by the inertia of established culture, including its given strategic perspective. And perhaps this school can also help us to understand a period of reframing, during which a new perspective develops collectively, and even a period of Cultural Revolution that tends to accompany strategic turnaround.

\subsection{Summary of the Cultural School}

The chapter discusses the background of the cultural school of strategic formulation by looking at the meaning of organizational culture, the premise of the cultural school, the relationship between culture and strategy, culture as a key resource in achieving competitive advantage, and critique and contribution of the cultural school. The school views strategic formulation as a social process rooted in culture and focuses on common interest and integration. The linkage between culture and strategy was summarized into 5 main subheadings; decision making style, resistance to change, overcoming the resistance to strategic change, dominant values and cultural clash.

Although the school discourages strategic change as it favors management of consistency, organizational culture is significant and key because cultural elements determine strategy. Culture, as a resource, provides organizations with a rare and imitable form of resources that makes it impossible for competitors to copy, thereby helping organizations to achieve competitive advantage.

\section{About Toyota Corporation}

Toyota Motor Corporation (TMC) or Toyota is a Japanese multinational auto- 
maker headquartered in Aichi, Japan with heavy presence in all continents of the world. In the 2016 fiscal year, Toyota employed 348,877 workers worldwide. As at the end of the 2016 fiscal year, Toyota sold 8, 681,000 units of cars and was ranked by Forbes as the $10^{\text {th }}$ largest public company in the world. Toyota is the only Japanese company and also the only automobile company to be among the top ten world largest public companies in 2016, making it the world largest automaker (Figure 1, Table 1).

The history of Toyota started in 1933 with the company being a division of Toyoda Automatic Loom Works devoted to the production of automobiles under the direction of the founder's son, Kiichiro Toyoda. Kiichiro Toyoda had traveled to Europe and the United States in 1929 to investigate automobile production and had begun researching gasoline-powered engines in 1930. Three years earlier, in 1934, while still a department of Toyota Industries, it created its first product, the Type Aengine, and, in 1936, its first passenger car, the Toyota AA. Toyota Motor Corporation group companies are Toyota (including the Scion brand), Lexus, Daihatsu and Hino Motors, along with several "non-automotive" companies. Toyota rather than Toyoda was chosen when the company

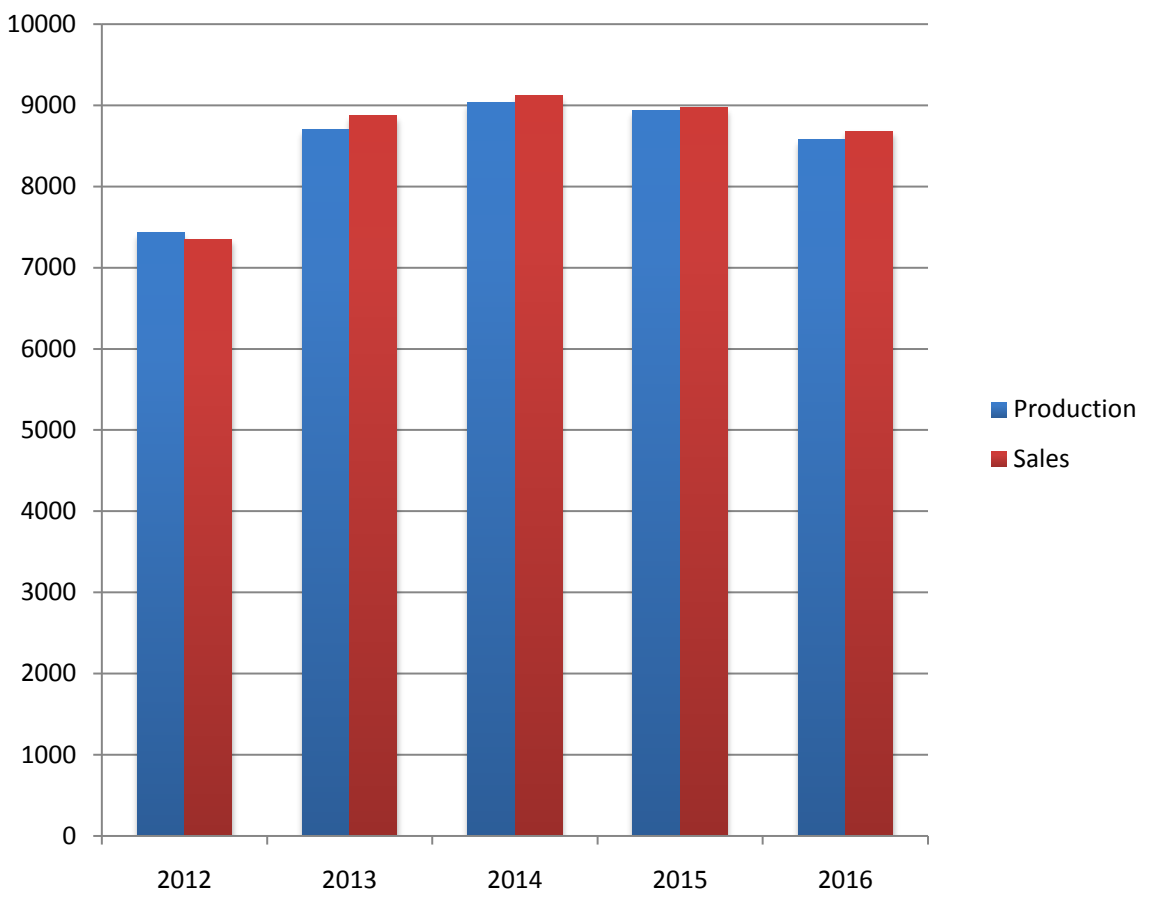

Figure 1. Prouctions and sales in 1000 of units (source: Toyota global website).

Table 1. Toyota operating income in billions of yuan.

\begin{tabular}{cccccc}
\hline & $\mathbf{2 0 1 2}$ & $\mathbf{2 0 1 3}$ & $\mathbf{2 0 1 4}$ & $\mathbf{2 0 1 5}$ & $\mathbf{2 0 1 6}$ \\
\hline NET REVENUE & 18,584 & 22,064 & 25,692 & 27,235 & 28,403 \\
OPERATING INCOME & 356 & 1321 & 2292 & 2750 & 2852 \\
$\begin{array}{c}\text { NET INCOME \& RETURN } \\
\text { ON EQUITY }\end{array}$ & 284 & 962 & 1823 & 2173 & 2313 \\
\hline
\end{tabular}

Source: Toyota global website. 
wanted to market and sell cars due to the simple reason that the stokes that made up Toyoda is more difficult and complex.

\subsection{Toyota's Case Analysis}

\subsubsection{Toyota Corporate Culture}

The fundamental reason for Toyota's success in the global marketplace lies in its corporate philosophy-the set of rules and attitudes that govern the use of its resources. Although the leadership of Toyota has helped in achieving successes over the years, the organizational culture of Toyota has played a major role in its strategic formulation. Culture, like leadership, is very important for the success of an organization and that one cannot function without the other [2]. It is very important to discuss about Toyota's organizational culture as cultural elements determine the strategy, goals and modes of operating of an organization. [2] argued that strategy cannot be separated from culture because strategic thinking is deeply colored tacit assumptions about organizations and their missions. [4] posited that organizational culture should form an important element of the strategic management process. Culture to a very large extent has significant effect on corporate strategy [8].

Two main pillars constitute Toyota organization culture, that is, Continues Improvement, and Respect for people. Continues Improvement is made of three key elements and [9] and explained as follows. First, Challenge, which involves long-term thinking, facing diverse problems risk, innovation new ideas and problem solving. Second is Kaizen, which means evolution, innovation and unending improvements in all areas of the company. Third is Genchi Genbitsu, which involves making the right decisions, agreements, and doing ones best in attaining organizational goals. The second pillar, Respect for people has two key elements. First is Respect, which involves respect for all people, avoidance of misunderstandings, acceptance of responsibilities by workers and mutual trust. Second is Teamwork, which emphasize on motivation of personnel, professional improvement and development of workers, and workers working as a team.

The founder of Toyota, Sakichi Toyoda has five main principles and these five principles forms the bases for the two pillars that constitutes the organizational culture enumerated above. According to [2] organizational culture is the reflection of the founders' beliefs and values. Among these five principles are for one to be always faithful in their duties and thereby contributing to the company and to the overall good. The second principle is to be studious always and creative in order to stay ahead all times. Third is to be practical always and avoid frivolousness. The forth is the desire to strive to build a homelike atmosphere at work that is warm and friendly. And finally, to always have respect for spiritual matters and remember to be grateful at all times. These five main principles have evolved over the years to become the seven main guiding principles of Toyota. [2] underscores the fact that, founders of any enterprise begin the culture process by imposing beliefs, values, and assumptions into new employees and if the new organization succeeds, then its cultural elements become shared and 
constitute the emerging culture of that organization. [2] concluded that organizational culture is a reflection of the founders' beliefs and values. Toyota's Global Vision adopted in 2011 is based on the seven guiding principles. These principles are:

- Honor the language and spirit of the law of every nation and undertake open and fair business activities to be a good corporate citizen of the world.

- Respect for the culture and customs of every nation

- Providing clean and safe products so as to enhance the quality of life everywhere through all activities.

- Providing outstanding products and services that fulfill the needs of customers worldwide.

- Fostering a corporate culture that enhances both individual creativity and the value of teamwork, while honoring mutual trust and respect between labor and management.

- Pursue growth through harmony with the global community via innovative management

- Work with business partners in research and manufacture to achieve stable, long-term growth and mutual benefits, while keeping open to new partnerships.

Toyota have successfully penetrated global markets and established a worldwide presence by virtue of its productivity. The company's approach to both product development and distribution is very consumer-friendly and marketdriven. Toyota's philosophy of empowering its workers is the centerpiece of a human resources management system that fosters creativity, continuous improvement, and innovation by encouraging employee participation, and that likewise engenders high levels of employee loyalty. Knowing that a workplace with high morale and job satisfaction is more likely to produce reliable, highquality products at affordable prices, Toyota have institutionalized many successful workforce practices. Toyota has done so not only in its own plants but also in supplier plants that was experiencing problems.

Although many car manufacturers have earned a reputation for building highquality cars, they have been unable to overcome Toyota's advantages in human resource management, supplier networks and distribution systems in the highly competitive car market. Toyota in Japan hires almost all of its new employees fresh out of school, in some cases from a Toyota City Technical High School, where students begin to learn the Toyota Way while still in school. Aspects of the Toyota Way are, in fact, intertwined with Japanese culture, which is relatively homogenous. Much of Toyota's success in the world markets is attributed directly to the synergistic performance of its policies in human resources management and supply-chain networks.

\subsubsection{The 4P's Model of the Toyota Way}

This section gives a brief explanation of the 4P's model of the "Toyota Way". These 4P's are Philosophy, Process, People and Partners, and Problem Solving as shown in Figure 2. 


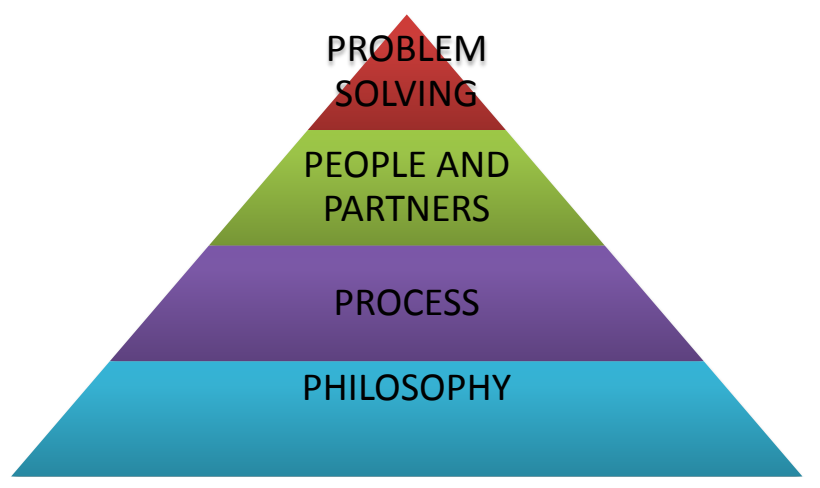

Figure 2. The 4PS model of the Toyota way.

1) PHILOSOPY: Toyota's philosophy lies in its belief to put customer needs ahead of everything else. This forms the basis for all the other principles. This has aided the company in producing quality cars and world-class services. The Customer First policy that was declared in May 1946 was meant to emphasize that the company's primary focus must and should always be the customer.

2) PROCESS: Toyota believes in following the right process as this will result in producing the right results. Whenever a decision has to be in solving a particular problem, the right processes must be followed. The key ideas hear is to eliminate waste and cost.

3) PEOPLE AND PARTNERS: Three key words are associated with this principle, that is respect, challenge, and grow. Toyota creates a challenging environment whereby employees and partners are always expected to think, learn and grow. Toyota believes leaders are grown but not bought and so employees are giving the necessary training and exposure. The organization can capture value by developing its people and partners.

4) PROBLEM SOLVING: Toyota beliefs in identifying the root cause of a problem to find out the actual cause before devising a solution. Whenever a problem arises, it must be fixed immediately rather to continue to production with the intention of fixing it later. Also all must share important lessons learnt in solving a problem so that similar problems do not occur.

\subsubsection{Toyota's Global Competitive Advantage}

In this competitive environment, a company's ability to stay on top of the competition has to do with the company's ability to exceed the expectation of its customers, and that is what Toyota is good at, that is, exceeding the expectation of its customers. Adding value to its customer is the basic philosophy of Toyota. This philosophy can be seen in the company's vision statement and guiding principles. Another area that gives Toyota competitive advantage is its employees. There is evidenced in literature that companies that have invested in their human resources achieve sustained competitive advantage in the long term [10]. Toyota treats its employees with dignity and respect and challenges the employees to always grow. Employees are being treated as a team and so every employee feels he is part of the continues improvement of the company. Tech- 
nology innovation has also given Toyota an edge over its competitors. In recent times, Toyota has introduced smaller energy efficient vehicles, as more and more consumers want to control their cost on energy consuming vehicles. [11] concluded that technological innovations and skillful workforce can be classified as the two main contributors of Toyota's success story.

Toyota's guiding principle of eliminating waste in the production system enabled the company to cut down on cost and thereby achieving a low cost of production. Companies that are able to control cost (as they have no control over revenue) are able to achieve competitive advantage over their peers. Toyota production system (TPS) to a large extent is the catalyst for the successes chalk in Toyota. The TPS is based on the philosophy of elimination of all waste in the production system. The system is founded on two concepts: the first is "Jikoda" meaning that when a problem occurs, the equipment stops immediately to prevent further production of defective products; and the second, "just in time" meaning that producing just what is needed, when it is needed and at the right quantity needed. These two concepts that founded that TPS is aimed at reducing cost.

\section{Conclusions}

The Cultural School of Strategic Formulation assumes that culture has important influence on strategy and that strategies are most likely to succeed when aligned with organizational culture. The school introduces ideas of collective cognition and organizational style. Culture is seen as a key resource in achieving sustained competitive advantage in the long run as it is difficult to be imitated.

The school views strategy formulation as a social process rooted in culture with much emphasis on how the influence of culture can discourage significant strategic change. To overcome the scenario whereby culture becomes a limitation to strategic change, the school suggested that top management must attach flexibility and innovation in a firm's culture. For any strategic change to be successful, it must be premised on changes in the firm's culture. The school proposes four phases that organizations must adopt to overcome the barrier of resistance to change, and this includes; strategic drift, breaking-down of the current change, trail and re-formulation, and stabilization.

The Cultural school helps us to understand a period of reframing, during which a new perspective develops collectively, and even a period of Cultural Revolution that tends to accompany strategic turnaround. The limitation of this research is that, the organizational culture of Toyota has been much researched and became the focus of study for many organizations. Future research should look at other organizations that also have their strategy rooted in their organizational culture. Other researchers can compare the organizational culture of Toyota to that of other organizations.

\section{References}

[1] Hofstede, G.J. (2010) Cultures and Organizations: Software of the Mind. McGraw- 
Hill, New York.

[2] Schein, E.H. (2009) Corporate Culture Survival.

[3] Sastre-castillo, A.O.M.Á. and Ortega-parra, A. (2013) Impact of Perceived Corporate Culture on Organizational Commitment. Management Decision, 51, 1071 1083.

[4] David, F.R. (2013) Strategic Management Concepts and Cases, Thirteenth. Prentice Hall, Upper Saddle River.

[5] Mintzberg, H., Ahlstrand, B. and Lampel, J. (1998) Strategy Safari Wilds of Strategic Management. Free Press, New York, 406.

[6] Struwig, F.W. and Smith, E.E. (2002) The Relationship between Organizational Culture and Strategy Formulation in South African Firms. South African Journal of Business Management, 33, 21-29.

[7] Hitt, M.A. and Ireland, R.D. (2009) Strategic Management: Competitiveness \& Globalization. 9th Edition, South-Western College Publishing, Mason.

[8] Schrivastava, P. (1985) Integrating Strategy Formulation with Organizational Culture. Journal of Business Strategy, 5, 103-111. https://doi.org/10.1108/eb039080

[9] Liker, J.K. and Hoseus, M. (2008) Toyota Culture: The Heart and Soul of the Toyota Way. McGraw-Hill, New York.

[10] Van Deusen, C. and Woods, L.A. (2008) Competitive Advantage the Toyota Way. Business Strategy Review, 14, 51-60.

[11] Elsey, B. and Fijiwawa, A. (2000) Kaizen and Technology Transfer Instructors as Work-Based Learning Facilitators in Overseas Transplants : A Case Study. Journal of Workplace Learning, 12, 333-341. https://doi.org/10.1108/13665620010378831 


\section{Internet Links}

http://www.toyota.com

Dhttp://www.managementstudyguide.com/edgar-schein-model.htm

$>$ http://www.valuebasedmanagement.net/methods_schein_three_levels_cultur e.html

$>$ http://www.toyota-global.com/company/profile/overview/

$>$ http://feaa.ucv.ro/AUCSSE/0038v3-004.pdf

$>$ http://www.1000ventures.com/business_guide/mgmt_kaizen_main.html

> http://www.toyota-global.com/sustainability/report/sr/pdf/sr12_p63.pdf

$>$ http://www.hreonline.com/HRE/view/story.jhtml?id=142379047

$>$ http://swdsi.org/swdsi07/2007_proceedings/papers/567.pdf

$>$ http://www.reliableplant.com/Read/10817/toyota-continuous-improvement

$>$ https://www.google.com/search?q=toyota + culture+change\&ie=utf-8\&oe=utf -8\&aq=t\&rls=org.mozilla:en-US:official\&client=firefox-a

$>$ http://www.1000advices.com/intro/kaizen_mindset_brief.html

$>$ http://ventures.powweb.com/business_guide/crosscuttings/sca_us_vs_japan. $\underline{\mathrm{html}}$

$>$ http://www.cbsnews.com/8301-505125_162-57362830/7-signs-of-a-high-perf ormance-company/

http://faculty.css.edu/dswenson/web/6300-OBOD/culturechange.html

Submit or recommend next manuscript to SCIRP and we will provide best service for you:

Accepting pre-submission inquiries through Email, Facebook, LinkedIn, Twitter, etc. A wide selection of journals (inclusive of 9 subjects, more than 200 journals)

Providing 24-hour high-quality service

User-friendly online submission system

Fair and swift peer-review system

Efficient typesetting and proofreading procedure

Display of the result of downloads and visits, as well as the number of cited articles

Maximum dissemination of your research work

Submit your manuscript at: http://papersubmission.scirp.org/

Or contact ojbm@scirp.org 